Role of agricultural engineering in environmental and sustainable development for the valley and delta areas: 1710 - 1720

\title{
EFFECT OF COATING TEMPRATURE AND TIME ON GERMINATION FOR SOME MEDICAL AND AROMATIC-CROP SEEDS
}

\author{
I. Yehia $^{(1)}$, M. Atallah ${ }^{(2)}$,A. Eliwa ${ }^{(3)}$, and A. M. El Lithy ${ }^{(4)}$
}

\begin{abstract}
The objective of this paper is to study the effect of coating temperature and its duration on germination percentage of some medical and aromatic crops (fennel, caraway, coriander, nigella and guar) seeds. The main results in this study can be summarized in the following points:

The fennel, caraway, coriander, nigella and guar seeds germination decreased by 22.5 - 22.9, 22.8 - 24.4, 18.9-29.8, 20.1 - 27.5 and 18.1$23.7 \%$ by increasing coating temperature from 40 to $70 C^{\circ}$. Meanwhile, the fennel, caraway, coriander, nigella and guar seeds germination decreased by 16.7 - 35.4, 17.1 - 36, 16.6 - 32.3, 15.2 - 32.2 and 14.3 $29.8 \%$ by increasing coating time from 30 to 60 min.

The maximum fennel, caraway, coriander, nigella and guar seeds germination of 98.1, 96, 98, 100 and $100 \%$ were obtained with coating temperature of $40 \mathrm{C}^{\circ}$ and coating time of $30 \mathrm{~min}$. Meanwhile, the minimum fennel, caraway, coriander, nigella and guar seeds germination of 63.38, 61.43, 66.3, 67.76 and 70.2 \% were obtained with coating temperature of $70 \mathrm{C}^{\circ}$ and coating time of $70 \mathrm{~min}$.
\end{abstract}

\section{INTRODUCTION}

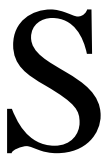

eeds vary greatly in size, shape and color. In many cases, seed size is small or irregular, making singularization and precision placement difficult. In addition, seeds should be protected from a range of pests that attack germination seeds or seedlings. Seed-coating technologies can be employed For two purposes: they can facilitate mechanical sowing to achieve uniformity of plant spacing, and can act as a carrier for plant protectants. So materials can be applied in the target zone with minimal disruption to the soil ecology and environment (Taylor et al., 1998).

(1), (2) and (3) Chief Res., Res. and Senior Res., Ag. Eng. Res. Inst. Respectively, (4) Associ. Prof, Ag. Eng., Ag. Col., Azhar U., Assiut. 
Film coating is a method adapted from the pharmaceutical and confectionery industries for uniform application of materials to seeds. The film forming formulation consists of a mixture of polymer, plasticizer and colorants (Halamer, 1998 and Robani, 1994), and formulations are commercially available that are ready-to-use liquids or prepared as dry powders (Ni, 1997). Application of the film-forming mixture results in uniform deposition of material on each seed with little variation among seeds (Halmer, 1998). The formed film may act as a physical barrier, which has been reported to reduce leaching of inhibitors from seed coverings and may restrict oxygen diffusion to the embryo (Duan and Burris, 1997). A standard pelleting pan has been adapted for application of film-coating polymers, and drying is achieved by applying forced warm air into the coating pan (Taylor and Eckenrode,1993). A small-scale. fluidized bed seed-coating apparatus has been described with controlled air velocity and temperature (Burris et al., 1994). Film coating is routinely performed in vented or perforated pans on a large-scale basis either on a batch or continuos system (Halmer, 1998 and Robani, 1994). The introduction of a continuous process vented-drum coating machine by Coating Machinery Systems (Huxely, Iowa) has expanded the use of film coating. This equipment is capable of continous application of various polmyer systems and components, while providing drying capacity to prevent the seed from hydrating. Capacities vary from 100 to $10000 \mathrm{~kg} / \mathrm{h}$ depending on seed type, and target weight gain.

Film coating is versatile as a coating system or a component of a coating system. Colorants as aesthetic appeal to seeds, serve to color-code different verities and increase the visibility of seeds after sowing. Filmcoated seeds have better flow characteristics in the planter (Hill, 1997) due to reduced friction between seeds. Film coating provides an ideal method for the application of chemical and / or biological seed treatments (Taylor et al., 1994 and McGee, 1995).

The cultivated area of wheat reached about 61.8 thousand feddan in 2002 that produces about 203.6 thousand ton of grains per year (Agricultural Statistics Economic Affair Sector, 2003).

Yehia (2008) designed a coating machine for crop seeds. It was found that the maximum wheat-grain germination of $98.1 \%$ was obtained with 
coating temperature of $40 \mathrm{C}^{\circ}$ and coating time of $30 \mathrm{~min}$. Meanwhile, the minimum wheat-grain germination of $38.3 \%$ was obtained with coating temperature of $70 \mathrm{C}^{\circ}$ and coating time of $60 \mathrm{~min}$.

The objective of this paper is to study the effect of coating temperature and duration on germination percentage of some medical and aromatic crop seeds

\section{MATERIALS AND METHODS}

Coating machine: The coating machine which designed by Yehia, 2008 was used in this study (fig. 1). The main specifications of this machine are: total height $120 \mathrm{~cm}$, width $56.5 \mathrm{~cm}$, depth $104 \mathrm{~cm}$, and total mass 80 $\mathrm{kg}$. The main coating machine parts are as follow:

(1) Frame: made of steal angle with dimensions of $4 \times 4 \times 0.4 \mathrm{~cm}$, height of $76.5 \mathrm{~cm}$, width of $43 \mathrm{~cm}$ and depth of $80 \mathrm{~cm}$.

(2) Feeding pan or unit: has a cylindrical shape made of stainless steal with diameter of $55 \mathrm{~cm}$, depth of $36 \mathrm{~cm}$ and with feeding opening with $37 \mathrm{~cm}$ diameter and $5 \mathrm{~cm}$ height.

(3) Gear box: with $8.5: 1$ speed ratio which transmits the motion to feeding unit by countershaft.

(4) Electric motor and power transmission: Electric motor of $1 \mathrm{hp}$ $(0.675 \mathrm{~kW})$ and $1400 \mathrm{rpm}$ and four pulleys with 3.8, 25, 6.3 and 19 diameters and belts.

Crop seeds: Fennel (Foeniculum), caraway (Curum), coriander, nigella and guar seeds were tested in this study.

Arabic gum solution: with 50 concentration was used.

Seed batch: of $5 \mathrm{~kg}$ was used.

Coating-unit speed: of $28 \mathrm{rpm}$ was used.

\section{Coating steps:}

(1) The wheat flour powder of $0.5 \mathrm{~kg}$ was spread inside the rotated coating pan (unit) which was heated by heater flame. The temperature of coating pan and grains was controlled by flame intensity.

(2) The medical and aromatic seeds batch $(5 \mathrm{~kg})$ was spread inside the rotating coating pan. 


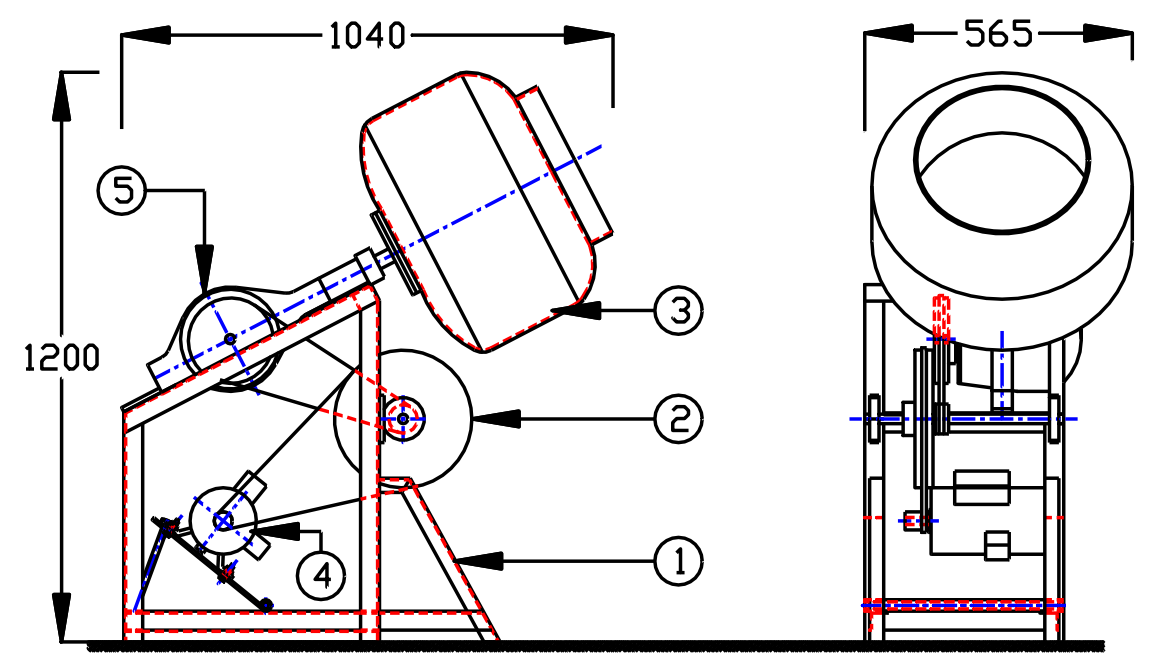

(1) frame, (2) idler pulley, (3) coating unit, (4) motor and (5) gear box.

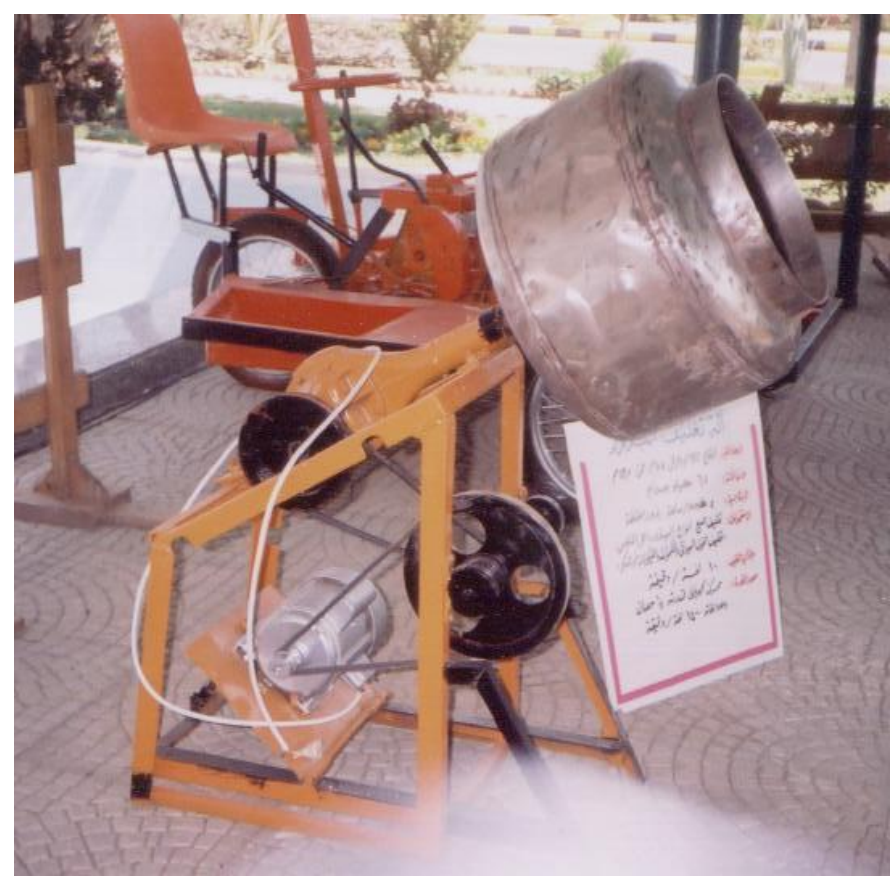

Fig. 1: Sketch and photograph of the coating machine (Yehia, 2008). 
(3) Arabic-gum solution with $75 \mathrm{~cm}^{3}$ volume was spread on the seeds inside coating pan.

(4) The grains were agitated by hand to distribute the Arabic gum.

(5) The wheat flour powder of about $70 \mathrm{~g}$ was spread directly after then.

(6) The grains were agitated by hand to distribute the flour powder to add it as a layer around the grains.

(7) The steps from 3 to 6 were repeated until finishing the first layer. The first layer needs $1: 2$ powder seeds ratio.

(8) The seeds exit from coating pan and spread in the air to dry.

(9) The dried coated-seeds were put inside coating pan.

(10) The steps from 3 to 6 were repeated until finishing the jacket layer. The jacket layer needs $0.3: 1$ wheat-flour powder seeds ratio.

(11) The grains exit from coating pan and spread in the air to dry.

\section{RESULTS AND DISCUSSION}

\section{Effect of coating temperature and time on germination of fennel seeds.}

Table 1 and fig. 2 show that the fennel seeds germination decreased by $22.5-22.9$ by increasing coating temperature from 40 to $70 \mathrm{C}^{\circ}$.

The maximum fennel seeds germination of $98.1 \%$ was obtained with coating temperature of $40 \mathrm{C}^{\mathrm{O}}$ and coating time of $30 \mathrm{~min}$. Meanwhile, the minimum fennel seeds germination of $63.38 \%$ was obtained with coating temperature of $70 \mathrm{C}^{\circ}$ and coating time of $70 \mathrm{~min}$.

Effect of coating temperature and time on germination of caraway seeds.

Table 1 and fig. 2 show that the caraway seeds germination range decreased from $74.1-96$ to $61.43-81.23 \%$ by increasing coating temperature from 40 to $70 \mathrm{C}^{\circ}$.

The maximum caraway seeds germination of $96 \%$ was obtained with coating temperature of $40 \mathrm{C}^{\mathrm{o}}$ and coating time of $30 \mathrm{~min}$. Meanwhile, the 
minimum caraway seeds germination of $61.43 \%$ was obtained with coating temperature of $70 \mathrm{C}^{\mathrm{O}}$ and coating time of $70 \mathrm{~min}$.

Table 1: Effect of coating temperature and time on germination of some medical and aromatic seeds.

\begin{tabular}{|c|c|c|c|c|}
\hline \multirow{3}{*}{ Seed type } & \multirow{3}{*}{$\begin{array}{c}\text { Coating } \\
\text { temperature, } \mathbf{c}^{0} \text {. }\end{array}$} & \multicolumn{3}{|c|}{ Germination ratio, $\%$. } \\
\hline & & \multicolumn{3}{|c|}{ Coating time, minute. } \\
\hline & & 30 & 45 & 60 \\
\hline \multirow{4}{*}{ Fennel } & 40 & 98.1 & 92.3 & 82.17 \\
\hline & 50 & 95.1 & 88.6 & 74.96 \\
\hline & 60 & 93.95 & 81.06 & 68.15 \\
\hline & 70 & 76.05 & 70.01 & 63.38 \\
\hline \multirow{4}{*}{ Caraway } & 40 & 96 & 85.17 & 81.23 \\
\hline & 50 & 89.35 & 86.13 & 69.84 \\
\hline & 60 & 81.06 & 79.13 & 70.45 \\
\hline & 70 & 74.1 & 66.3 & 61.43 \\
\hline \multirow{4}{*}{ Coriander } & 40 & 98 & 96.5 & 94.5 \\
\hline & 50 & 86.4 & 83.16 & 71.78 \\
\hline & 60 & 80.09 & 76.24 & 70.93 \\
\hline & 70 & 79.46 & 73.13 & 66.3 \\
\hline \multirow{4}{*}{ Nigella } & 40 & 100 & 99.44 & 93.5 \\
\hline & 50 & 91.11 & 80.19 & 79.54 \\
\hline & 60 & 82.03 & 78.18 & 69.19 \\
\hline & 70 & 79.95 & 71.18 & 67.76 \\
\hline \multirow{4}{*}{ Guar } & 40 & 100 & 92.11 & 92.01 \\
\hline & 50 & 93.2 & 87.12 & 83.42 \\
\hline & 60 & 82.99 & 78.5 & 71.41 \\
\hline & 70 & 81.9 & 76.05 & 70.2 \\
\hline
\end{tabular}



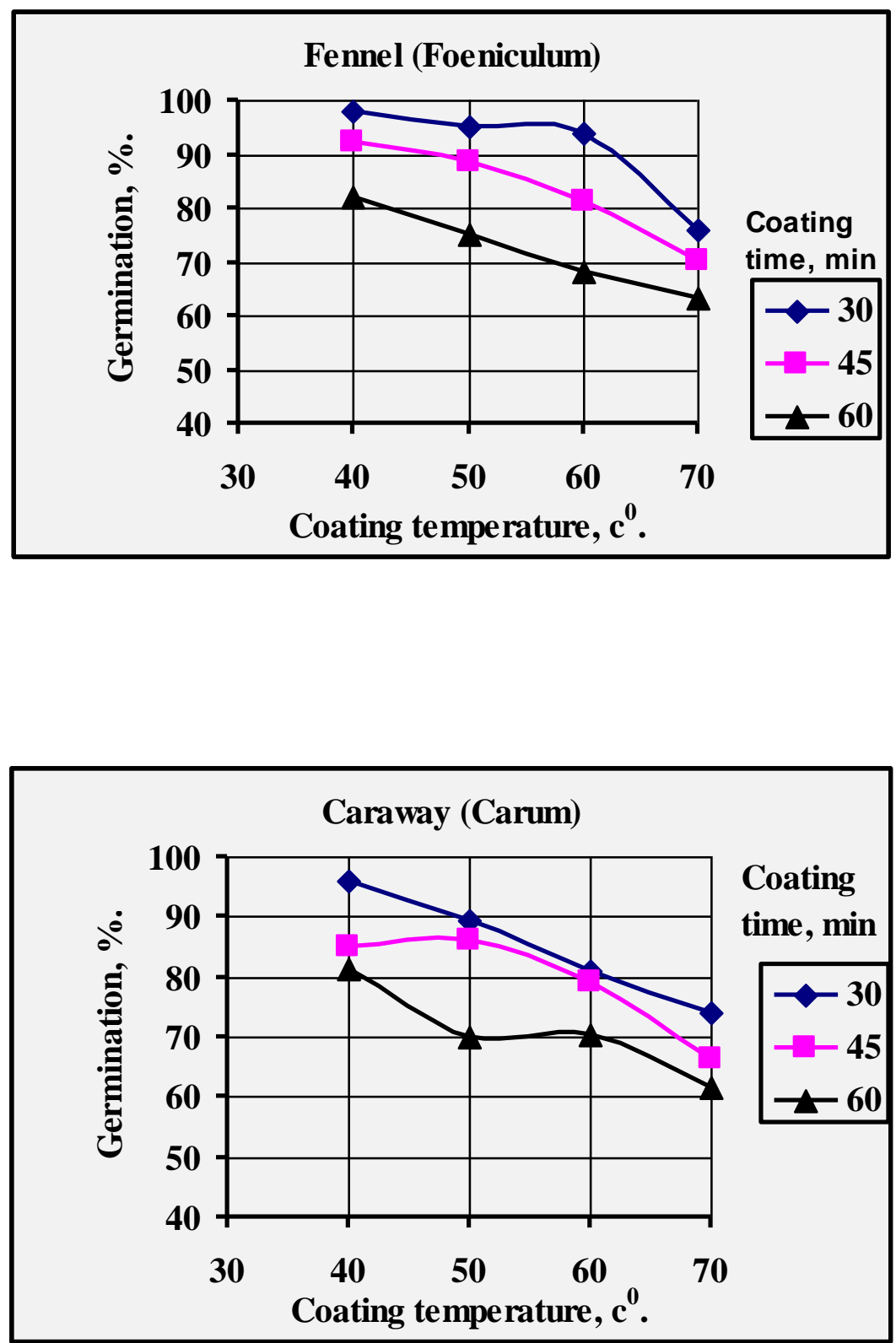

Fig. 2: Effect of coating temperature and time on germination of funnel and caraway seeds. 
Effect of coating temperature and time on germination of coriander seeds.

Table 1 and fig. 3 show that the average coriander seeds germination decreased from 86 to $75.9 \%$ by increasing coating temperature from 40 to $70 \mathrm{C}^{\circ}$.

The maximum coriander seeds germination of $98 \%$ was obtained with coating temperature of $40 \mathrm{C}^{\circ}$ and coating time of $30 \mathrm{~min}$. Meanwhile, the minimum coriander seeds germination of $66.3 \%$ was obtained with coating temperature of $70 \mathrm{C}^{\mathrm{O}}$ and coating time of $70 \mathrm{~min}$.

Effect of coating temperature and time on germination of nigella seeds.

Table 1 and fig. 3 show that the average nigella seeds germination decreased from 88.3 to $77.5 \%$ by increasing coating temperature from 40 to $70 \mathrm{C}^{\circ}$.

The maximum nigella seeds germination of $100 \%$ was obtained with coating temperature of $40 \mathrm{C}^{\circ}$ and coating time of $30 \mathrm{~min}$. Meanwhile, the minimum nigella seeds germination of $67.76 \%$ was obtained with coating temperature of $70 \mathrm{C}^{\circ}$ and coating time of $70 \mathrm{~min}$.

\section{Effect of coating temperature and time on germination of guar seeds.}

Table 1 and fig. 3 show that the average guar seeds germination decreased from 89.5 to $79.3 \%$ by increasing coating temperature from 40 to $70 \mathrm{C}^{\circ}$.

The maximum guar seeds germination of $100 \%$ was obtained with coating temperature of $40 \mathrm{C}^{\circ}$ and coating time of $30 \mathrm{~min}$. Meanwhile, the minimum guar seeds germination of $70.2 \%$ was obtained with coating temperature of $70 \mathrm{C}^{\circ}$ and coating time of $70 \mathrm{~min}$.

\section{CONCLUSION}

The maximum fennel, caraway, coriander, nigella and guar seeds germination of 98.1, 96, 98, 100 and $100 \%$ were obtained with coating temperature of $40 \mathrm{C}^{\mathrm{o}}$ and coating time of $30 \mathrm{~min}$. Meanwhile, the minimum fennel, caraway, coriander, nigella and guar seeds germination of $63.38,61.43,66.3,67.76$ and $70.2 \%$ were obtained with coating temperature of $70 \mathrm{C}^{\circ}$ and coating time of $70 \mathrm{~min}$. 

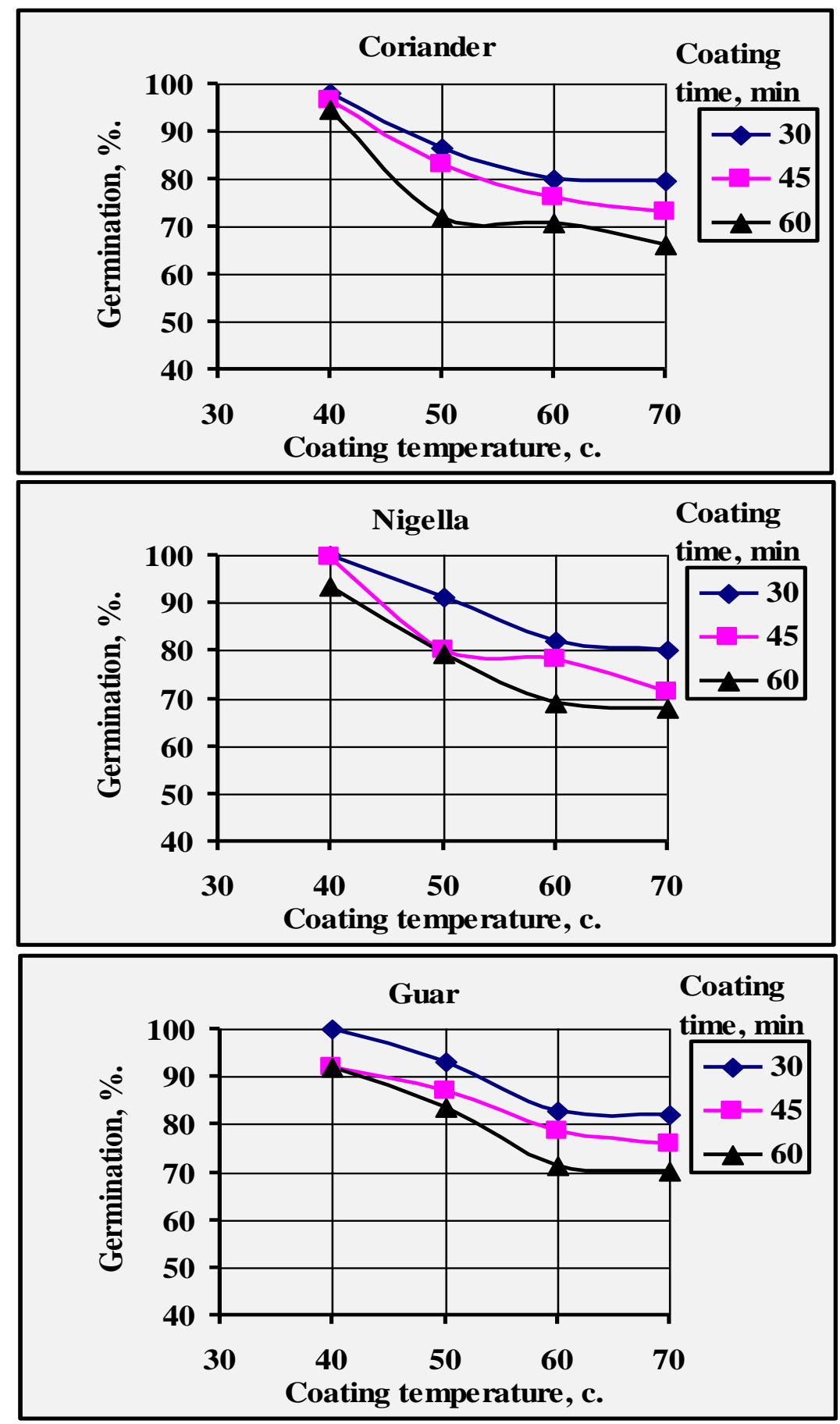

Fig. 3: Effect of coating temperature and time on germination of coriander, nigella and guar seeds. 


\section{REFFERENCES}

Agricultural Economics Issue, 2003, Central Management of Ag. Economics, Ministry of Ag., Egypt: $1-5$.

Burris, J. S., Prijic, L. M. And Chen, Y., 1994, A small-scale laboratory fluidized bed seed-coating appratus pp 419-423 in Martin, T. (Ed.), Seed Treatmrent Progress and Prospects, Surrey, British Crop Prot. Council.

Duan, X. and Burris, J. S., 1997, Film coating impairs leaching of germination inhibitors in sugar beet seeds, Crop Science 37 :515520 .

Halmer, P., 1998, Technical and commercial aspects of seed pelleting and film-coating, pp 191-204 in Martin, T. (Ed.), Seed Treatmrent Progress and Prospects, Surrey, British Crop Protection Council.

Hill, H. J., 1997, New developments in seed technology, Proceedings of the Oregon Hort. Soc., Portland, Oregon 88: 123-130.

McGee, D. C., 1995, Advances in seed treatment technology, Technical report no. 11, pp 1-14 in McNicoll, A. (Ed.) Proc. Asia and Pacific Seed Assoc., New Delhi, APSA.

Ni, B. R., 1997, Seed coating, film coating and pelleting, pp 737-747 in Chinese Assoc. of Ag. Sci., DDA, Minis. of Ag., PR China and China Nat. Seed Group Cooperation, (ED.), Seed industry and ag. Dev., Bejing, China Ag. Press.

Robani, H., 1994, Film-coating horticultural seed, HorTech. 4: 104-104.

Taylor, A. G. and Eckenrode, C. J., 1993, Seed coating technologies to apply Trigard for the control of onion maggot and to reduce pesticide application, pp 73-78 in Efforts pertinent to the integrated pest manag. effort at Corrnel U., 1998, NYS IPM Pub. 117.

Taylor. A. G., Harman, G. E. and Nielsen, P. A., 1994, Biological seed treatments using Trichodrina harzianum for horticultural crops, HorTech. 4: 105-109. 
Taylor, A. G., Allen, P. S., Bennett, M. A., Bardford, K. J., Burris, J. S. And Misra, M. K., 1 998, Seed enhancements, Seed Sc. Res. 8, USA: $245-256$.

Yehia, I., 2008, Factors affecting the design of coating machine for crop seeds, Misr J. Ag. Eng., 25(1): 147-159.

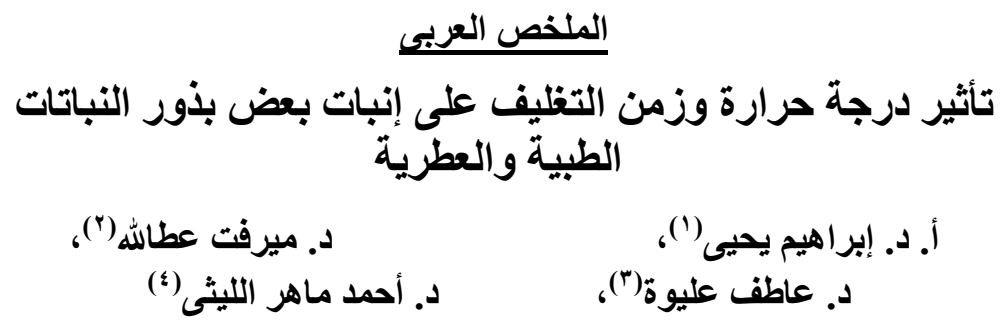

يهدف هذا البحث إلى دراسة تأثير درجة حرارة وزمن التغليف على إنبات بعض بذور النبتات

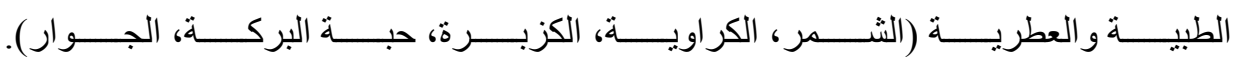

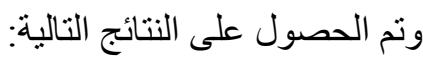

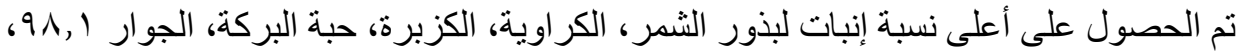

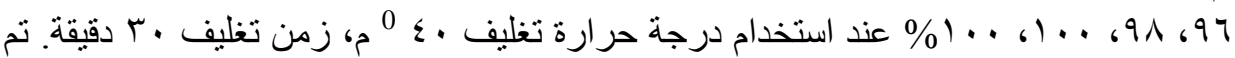

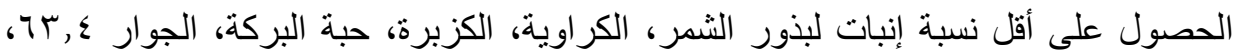

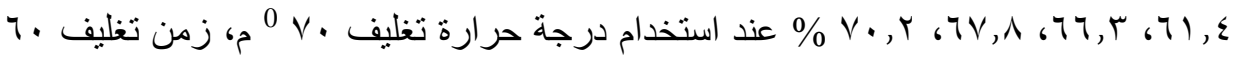
دقيقة.

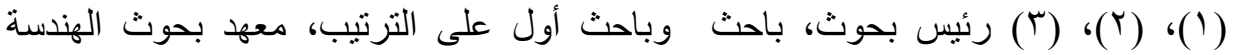

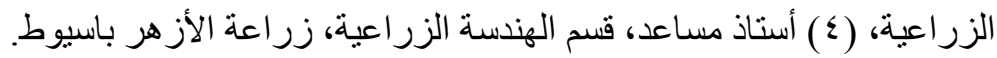

